\title{
The Influence Of Product Quality, Price, Brand Image And Promotion On The Purchase Decision Of Xiaomi Smartphone Products In Depok City
}

\author{
Faramita Dwitama \\ Faculty Economic, Universitas Gunadarma \\ *Corresponding Author: \\ Email: faramita@staff.gunadarma.ac.id
}

\begin{abstract}
.
Technological developments and a lot of competitors in the smartphone industry make the competition tighter so that it triggers consumers to be more picky before deciding to make a purchase. Xiaomi is one of the manufacturers engaged in the production of smartphones which is well known in Indonesia. The purpose of this study is to determine whether product quality, price, brand image, and promotion can partially and simultaneously influence purchasing decisions for Xiaomi smartphones in Depok. This study uses quantitative primary data in the form of a questionnaire with a research sample of 100 respondents. The analytical tools used are validity test, reliability test, multicollinearity test, heteroscedasticity test, multiple linear regression analysis, normality test, coefficient of determination, $t$ test and $f$ test assisted by SPSS version 25 software. The results of this study are product quality, price, brand image, and promotion have a significant influence on purchasing decisions for Xiaomi smartphones in Depok city, either partially or simultaneously.
\end{abstract}

Keywords: Brand image, price, purchasing decisions, product quality, promotion

\section{INTRODUCTION}

Technological developments are growing rapidly and the need for the technology needed by humans is increasing, which will automatically encourage companies to compete in creating a product. One of the products that affect the current technological developments are the products of mobile phone /smartphone.At this time the need for technology is not only needed by urban communities but also rural communities who also need the development of this technology to facilitate communication or also facilitate other activities. Currently, there are many companies engaged in technology that have produced smartphones, each company is competing in creating a product that can compete with other brands in order to be accepted in a wide market. The number of companies that produce smartphones will form a mindset before making a purchase decision. Consumers will evaluate or compare a product with other products. Usually, consumers will compare product quality, price, brand image , and others. In addition, promotion is also very very influential in decision-making by consumers because promotion is the first thing that can introduce or provide product information to consumers. Xiaomi Inc. is a technology company. Th is private electronics company was founded on June 6, 2010, in China with its head office in Beijing.

This company started to enter the Indonesian market in 2014, at that time the Indonesian people were very enthusiastic about the products released by this company because it could surprise the smartphone industry by releasing devices that had the best specifications at a price that could be said to be quite cheap compared to its competitors. In the rankings top smartphone,vendors Indonesian, Xiaomi, ranked 3rd in their product sales in the 4 th quarter of 2020, while in the 1st quarter of 2021, Xiaomi experienced a decrease imposition $2^{\text {nd }}$ due to an increase in unit share of $3 \%$. Meanwhile, BBK Electronics or also known as BBK Group which is the parent brand of Oppo, Vivo and Realme, in the first quarter of 2021 BBK Group will get $55 \%$ unit share. it can be seen if the BBK Group succeeded in dominating the market share in Indonesia with a high unit share value. Based on this, the researcher feels it is important to examine how the influence of product quality, price, brand image, and promotion can influence purchasing decisions made by consumers and also if it can be a reference for Xiaomi companies to become more developed in Indonesia so that they can help determine marketing strategies. so that the planned sales targets can be realized. Based on the above background, the researchers are interested in researching "The Influence of Product Quality, Price, Brand Image and Promotion on Purchase Decisions for Xiaomi Smartphone Products". 


\section{LITERATURE REVIEW}

\section{Product Quality}

Product quality is a statement of the level of ability of a particular product in carrying out the expected function. Assauri (2015).

H1: Product quality variable has a significant effect on purchasing decision.

\section{Price}

Price is the amount of money that is sacrificed for an item or service, or the value of the consumer that is exchanged for benefits, ownership, use of the product or service. Suparyanto and Rosad (2015).

\section{H2: Price has a significant effect on the purchasing decision.}

\section{Brand Image Brand}

Image is the consumer's perception of a brand as a reflection of associations or memories that exist in the minds of consumers. Kotler and Keller (2016).

\section{H3: Brand image has a significant effect on purchasing decision.}

\section{Promotion}

Promotion is an activity carried out by a company to communicate the benefits of a product and as a tool to influence consumers in purchasing activities or using services according to their needs. Lupioyadi(2014).

H4: The promotion variable has a significant effect on the purchasing decision variable.

\section{Purchase Decision}

Purchase decision is the decision stage where consumers actually make the purchase process on a product. Tjiptono (2012).

H5: Product quality, price, brand image and promotion variables have a significant effect on purchasing decision.

\section{Thinking Framework}

Based on the literature review and the background that has been described, the research model and hypotheses are as shown in Figure 1

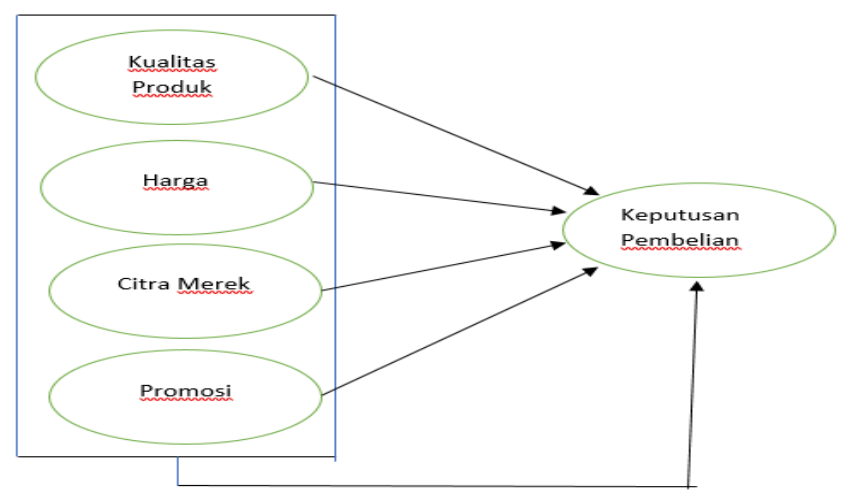

Fig1. Research model

\section{RESEARCH METHODS}

In this study, the population used were consumers of Xiaomi smartphone products in the city of Depok by using the same sampling method. by Paul Leedy. The number of samples in this study was 100 respondents. The sampling technique in this study used the accidental sampling technique, namely the sampling technique based on chance or incidental encounters with the researcher can be used as a sample, if the respondent has the criteria that the researcher needs. The analysis technique used is the test of validity, reliability, classical assumption test, multiple linear regression test, test of the coefficient of determination, $\mathrm{t}$ and f tests. In this study there are 4 independent variables, namely $\mathrm{X} 1$ as product quality, $\mathrm{X} 2$ as price, $\mathrm{X} 3$ as brand image, $\mathrm{X} 4$ as promotion and the dependent variable is $\mathrm{Y}$ as a purchase decision.

IV. Results and Discussion

\section{Validity and Reliability Test}

In the validity test of decision making can be said to be valid if $r$ hitung $\geq r$ tabel 
Tabel 1. Validity Test

\begin{tabular}{|c|c|c|c|}
\hline $\begin{array}{c}\text { Variabe } \\
\text { l }\end{array}$ & $\begin{array}{c}\text { R- } \\
\text { Hitung }\end{array}$ & $\begin{array}{c}\text { R- } \\
\text { Tabel }\end{array}$ & $\begin{array}{c}\text { Keteran } \\
\text { gan }\end{array}$ \\
\hline X1.1 & 0,628 & 0,1966 & Valid \\
\hline X1.2 & 0,751 & 0,1966 & Valid \\
\hline X1.3 & 0,689 & 0,1966 & Valid \\
\hline X1.4 & 0,579 & 0,1966 & Valid \\
\hline X1.5 & 0,499 & 0,1966 & Valid \\
\hline X1.6 & 0,442 & 0,1966 & Valid \\
\hline X1.7 & 0,365 & 0,1966 & Valid \\
\hline X2.1 & 0,622 & 0,1966 & Valid \\
\hline X2.2 & 0,720 & 0,1966 & Valid \\
\hline X2.3 & 0,710 & 0,1966 & Valid \\
\hline X2.4 & 0,686 & 0,1966 & Valid \\
\hline X3.1 & 0,728 & 0,1966 & Valid \\
\hline X3.2 & 0,642 & 0,1966 & Valid \\
\hline X3.3 & 0,602 & 0,1966 & Valid \\
\hline X3.4 & 0,770 & 0,1966 & Valid \\
\hline X4.1 & 0,736 & 0,1966 & Valid \\
\hline X4.2 & 0,528 & 0,1966 & Valid \\
\hline X4.3 & 0,732 & 0,1966 & Valid \\
\hline X4.4 & 0,721 & 0,1966 & Valid \\
\hline Y.1 & 0,704 & 0,1966 & Valid \\
\hline Y.2 & 0,482 & 0,1966 & Valid \\
\hline Y.3 & 0,778 & 0,1966 & Valid \\
\hline Y.4 & 0,432 & 0,1966 & Valid \\
\hline Y.5 & 0,635 & 0,1966 & Valid \\
\hline
\end{tabular}

Source: Data processed by spss 25 (2021)

In the calculation of reliability ifvalue Cronbach's Alpha $>0.60$ then a variable can be said to be reliable.

Tabel 2. Reliability Test

\begin{tabular}{|c|c|c|}
\hline variabel & $\begin{array}{c}\text { Alpha } \\
\text { Cronbach's }\end{array}$ & $\begin{array}{c}\text { keterang } \\
\text { an }\end{array}$ \\
\hline $\mathrm{X} 1$ & 0,658 & Reliabel \\
\hline $\mathrm{X} 2$ & 0,619 & Reliabel \\
\hline $\mathrm{X} 3$ & 0,626 & Reliabel \\
\hline $\mathrm{X} 4$ & 0,616 & Reliabel \\
\hline $\mathrm{Y}$ & 0,616 & Reliabel \\
\hline
\end{tabular}

Source: Data processed by spss 25 (2021)

In the calculation of reliability ifvalue Cronbach's Alpha $>0.60$ then a variable can be said to be reliable.

\section{Classical assumption test}

a. Normality Test

Table 3. Normality Test

One-Sample Kolmogorov-Smirnov Test

\begin{tabular}{|l|c|}
\hline & $\begin{array}{c}\text { Unstandardized } \\
\text { Residual }\end{array}$ \\
\hline Asymp. Sig. (2-tailed) & $.171 \mathrm{c}$ \\
\hline Source: Data processed by spss 25 (2021)
\end{tabular}

The normality test is often used in the SPSS program, namely the Kolmogorov-Smirnov Test with results Asymp. Sig. (2-tailed) is 0.171 greater than 0.05 . then the data is normally distributed.

b. Multicollinearity test

Based on the results of table 4, the product quality, price, brand image, and promotion variables have a vif value less than 10 , so there are no symptoms of multicollinearity. 
Tabel 4. Multicollinearity Test

\begin{tabular}{|c|c|}
\hline \multirow{2}{*}{ Variabel } & Collinearity Statistics \\
\cline { 2 - 2 } & Tolerance \\
\hline Product quality & .486 \\
\hline Price & .433 \\
\hline Brand image & .369 \\
\hline Promotion & .390 \\
\hline
\end{tabular}

Source: Data processed by spss 25 (2021)

\section{c. Heteroskidastity Test}

Based on table 5 the variables of product quality, price, brand image and promotion have a value greater than 0.05 then there is no symptom of heteroscedasticity.

Tabel 5. Heteroskidastity Test

\begin{tabular}{|c|c|}
\hline Variabel & Sig. \\
\hline $\begin{array}{c}\text { Product } \\
\text { quality }\end{array}$ & .662 \\
\hline Price & .119 \\
\hline Brand image & .889 \\
\hline Promotion & .257 \\
\hline
\end{tabular}

Source: Data processed by spss 25 (2021)

\section{Multiple Linear Analysis}

Tabel 6. Multiple Linear Analysis

\begin{tabular}{|c|c|}
\hline Variabel & B \\
\hline (Constant) & 3.253 \\
\hline Product quality & .141 \\
\hline Price & .249 \\
\hline Brand image & .384 \\
\hline Promotion & .187 \\
\hline
\end{tabular}

Source: Data processed by spss 25 (2021)

Based on the results of table 6 the following regression is obtained: $\mathrm{Y}=3.253+0.141 \mathrm{X} 1+0.249 \mathrm{X} 2+0.384 \mathrm{X} 3+0.187 \mathrm{X} 4+\mathrm{e}$

1. Coefficient The regression for the product quality variable (X1) shows a positive value of 0.141 , which means that if the product quality variable increases and the other independent variables have a fixed value, the level of purchasing decisions will increase by 0.141 units.

2. The regression coefficient for the price variable (X2) shows a positive value of 0.249 , which means that if the price variable increases and the other independent variables have a fixed value, the level of purchasing decisions will increase by 0.249 units.

3. The regression coefficient for the brand image variable (X3) shows a positive value of 0.384 , which means that if the price variable increases and other independent variables have a fixed value, the level of purchasing decisions will increase by 0.384 units

4. The regression coefficient for the promotion variable (X4) shows a positive value of 0.187 , which means that if the price variable increases and other independent variables have a fixed value, the level of purchasing decisions will increase by 0.187 units.

\section{Coefficient of Determination}

Based on the test results obtained, the value of Adjusted R Square is 0.675 , which means that the independent variables are product quality $(\mathrm{X} 1)$, price $(\mathrm{X} 2)$, brand image $(\mathrm{X} 3)$, promotion $(\mathrm{x} 4)$ explaining the dependent variable, namely purchasing decisions. of $67.5 \%$ while the remaining 32.5 is explained by other variables not included in this study.

Tabel 7. Coefficient Determination

\begin{tabular}{|l|c|r|r|r|}
\hline $\begin{array}{l}\text { Mode } \\
1\end{array}$ & $\mathrm{R}$ & $\begin{array}{c}\mathrm{R} \\
\text { Square }\end{array}$ & $\begin{array}{c}\text { Adjuste } \\
\mathrm{d} \mathrm{R} \\
\text { Square }\end{array}$ & $\begin{array}{c}\text { Std. Error } \\
\text { of the } \\
\text { Estimate }\end{array}$ \\
\hline 1 & $.829^{\mathrm{a}}$ & .688 & .675 & 1.103 \\
\hline
\end{tabular}

Source: Data processed by spss 25 (2021) 


\section{T Test (Partial)}

Tabel 8. $\mathrm{T}$ Test

\begin{tabular}{|c|c|c|}
\hline Variabel & $\mathrm{t}$ & Sig. \\
\hline Product quality & 2.365 & .020 \\
\hline Price & 2.514 & .014 \\
\hline Brand image & 3.807 & .000 \\
\hline Promotion & 2.005 & .048 \\
\hline
\end{tabular}

Source: Data processed by spss 25 (2021)

Based on table 8 product quality, price, brand image and promotion variables have a sig $<0$ value .50 and the value of $t$ arithmetic $>t$ table $($ ttable $=1.985)$ which indicates that this variable has a significant effect.

\section{F test (simultaneous)}

Tabel 9. F Test

\begin{tabular}{|c|c|c|}
\hline Variabel & $\mathrm{f}$ & Sig. \\
\hline $\begin{array}{l}\text { Keputusan } \\
\text { pembelian }\end{array}$ & 52.387 & $.000^{\mathrm{b}}$ \\
\hline
\end{tabular}

Source: Data processed by spss 25 (2021)

Obtained an F value of 52,387 with a significance level of 0.000. From these results, where F Count $>$ F Table (52.387 > 2.46). It can be concluded that product quality, price, brand image, and promotion together affect the decision to purchase xiaomi smartphone products in the city of Depok.

\section{Conclusion}

Based on the results of research and discussion of the influence of product quality, price, brand image and promotion on purchasing decisions for Xiaomi smartphone products in Depok City, it can be concluded as follows:

1. Product quality has a significant partial effect on purchasing decision variables for Xiaomi Smartphone products in the city of Depok City.

2. Price has a significant partial effect on the purchasing decision variables for Xiaomi smartphone products in the city of Depok.

3. Brand image has a significant partial effect on purchasing decision variables for Xiaomi smartphone products in the city of Depok.

4. Promotion has a significant partial effect on purchasing decisions for Xiaomi smartphone products in the city of Depok.

5. Product quality, price, brand image, and promotion simultaneously have a significant effect on purchasing decisions for Xiaomi smartphone products in the city of Depok.

\section{IMPLICATIONS}

1. Product quality variable is known to have an influence on purchasing decisions. It is shows that the quality of the products supplied by the company can be said to have been in accordance with what is expected by the consumer. So the company should be able to keep up or improve the quality of the smartphones they produce because the better the quality of a product it will give a positive or good impression to consumers in the process of evaluating or selecting products to be purchased

2. Price variables are known to have an influence on purchasing decisions. This shows that the price offered can be said to be affordable, in accordance with the product quality, benefits and the price offered has competitiveness against other smartphone products. So companies should still pay attention to whether the products they will market are in accordance with what consumers want, if the price offered is in accordance with what consumers want then customers will not hesitate to make purchases on the products offered.

3. The brand image variable is known to have a dominant influence in this study which was tested with the Standardized Coefficients Beta highest. Companies are obliged to pay attention to the brand image of their company, because the brand image is an assessment or view of the good or bad of a product issued 
by the company. With a good brand image, consumers will feel more confident about the product they want so that the potential for purchasing decisions will increase.

4. Promotional variables are known to have an influence on purchasing decisions.

Promotion is a form of communication between the company and its customers, the promotion has properties inform, and influence potential customers. If the company can increase the promotions they to provide information to the wider community in the hope that purchasing decisions can improve.

\section{REFERENCES}

[1] Assauri, S. (2017). Manajemen Pemasaran. Jakarta: PT RajaGrafindo Persada.

[2] Kotler, Phillip dan Kevin Lane Keller.(2016). Manajemen Pemasaran Edisi 12 Jilid 1 \& 2.Jakarta: PT. Indeks.

[3] Lupiyoadi, Rambat. 2014. Manajemen Pemasaran Jasa Berbasis Kompetensi. Edisi ke-3. Jakarta: Salemba Empat.

[4] Sugiarto, Sitinjak. (2006). Lisrel. Edisi Pertama. Cetakan Pertama Yogyakarta: Graha Ilmu.

[5] Sugiyono. (2014). Metode Penelitian Kuantitatif, Kualitatif, dan R\&D. Bandung: Alfabeta.

[6] Suparyanto \& Rosad. 2015. Manajemen Pemasaran, Yogyakarta: In Media.

[7] Tjiptono, F. (2012). Strategi Pemasaran. Yogyakarta: Andi. 